\title{
Individual foundings and organizational foundings: their effect on employment growth in The Netherlands
}

\author{
Sierdjan Koster
}

Accepted: 27 December 2008/Published online: 13 December 2009

(C) The Author(s) 2009. This article is published with open access at Springerlink.com

\begin{abstract}
This study addresses the question of whether different types of new firm formation have different impacts on regional employment generation. It is shown that new establishments of existing firms, i.e., organizational foundings, have a mainly shortterm positive effect. In contrast, genuinely new firms, i.e., individual foundings, have a longer-lasting effect. Individual foundings are based on the recognition of business opportunities and spur a process of creative destruction spanning a few years. Organizational foundings can be seen as capitalizations of scale economies. They have an immediate effect, but appear to be less relevant for structural change in a regional economy.
\end{abstract}

Keywords Entrepreneurship - Regional development · Organizational foundings ·

The Netherlands

JEL Classifications $\quad \mathrm{L} 26 \cdot \mathrm{O} 12 \cdot \mathrm{O} 18 \cdot \mathrm{R} 11$

\section{Introduction}

Ever since the seminal work of Birch (1979), in which he asserted the important role of small firms in

S. Koster $(\square)$

Faculty of Spatial Science, Urban and Regional Studies

Institute, Groningen University, P.O. Box 800,

9700 AV Groningen, The Netherlands

e-mail: sierdjan.koster@rug.nl the generation of employment, there has been a blossoming strand of literature devoted to small-firm dynamics and their impact on regional economic development in general and employment generation in particular. One typical approach is to analyze regional employment development by using regional start-up rates while controlling for other factors. Although the majority of studies find time-lagged, positive relationships between new firm formation and consequent employment generation (see, for example, Braunerhjelm and Borgman 2004; Acs and Armington 2004; Fölster 2000), the positive relationship is not without debate. Particularly in Europe, there is mixed evidence. Audretsch and Fritsch (2002), studying German regions, did find a positive effect for the 1990s, but not for the 1980s. In a similar vein, van Stel and Storey (2004) found positive effects for England, but not for Wales or Scotland. Using more recent data, Mueller et al. (2008) also failed to find a positive influence of new firm formation on employment development in Scotland. The mixed evidence has led to the idea that there may be structural dimensions influencing the effect of new firm formation on employment generation that could explain the inconsistent outcomes. Firstly, there may be regional differences in the effect of new firm formation on employment generation; that is, regional characteristics may affect the impact of new firms on employment (Fritsch and Schroeter this issue; Shrestha et al. 2007). Secondly, there is a significant temporal dimension to the 
relationship. New firm formation not only has an immediate effect on employment, it is also expected to have an effect 1, 2 years, etc. down the line. The overall effect of new firm formation is the cumulation of influences over many years (Fritsch and Mueller 2004; Fritsch 2008). Thirdly, the nature of the startups may have an impact. Some types of new firms are likely to have a stronger impact on employment generation than others (Klepper 2001; Wong et al. 2005; Audretsch and Keilbach 2004; Baptista and Preto this issue). This article further develops the argument involving different types of foundings by assessing the impact of two distinct forms-individual foundings and organizational foundings - on employment generation in Dutch regions. By using a longitudinal approach, the article also provides further empirical evidence for the time lag in the relationship between founding and employment generation.

In terms of employment growth, new firms are typically viewed as a uniform group. Particularly in empirical approaches, new firm formation is generally interpreted as a representation of entrepreneurial activity in a Schumpeterian sense. This, however, seems to be somewhat of an oversimplification: most new firms do not introduce any new products or seek out new markets (Bosma and Harding 2007). In addition, the daily activities of founders can often be strikingly similar to their daily activities when still employed (Koster 2006). Although it can be argued that all new firms involve risk-taking and must therefore be seen as entrepreneurial, it is apparent that different kinds of new firm formations may have different impacts on regional economic development and employment growth. Regions may even have the wrong type of new firm formation in this regard (Davidson and Ekelund 1994; Baumol 1990; Mueller et al. 2008). At the firm level, it has already been established that some new firms outperform others. Spin-off companies, for example, are more viable than firms that are not based on previous industry experience (Klepper 2001; Koster 2006). Also, firms started by habitual founders generally outperform firms started by one-off founders (see, for example, Ucbasaran et al. 2006). These stylized facts at the firm level have, however, rarely been incorporated in regional models of the relationships between new firm formation and economic development or employment generation. The study by Wong et al.
(2005) is an exception and finds, at the country level, that only the formation of high-expectation firms contributes to economic growth. In a similar vein, Audretsch and Keilbach (2004) find positive effects of new firm formation in the form of high-technology foundings and information and communication technology (ICT) foundings. Finally, Acs and Mueller (2008) find that large start-ups have a greater impact on employment generation than do small start-ups, not only in the short term, as is logical, but also in the longer term.

The current study aligns with these studies by simultaneously assessing the impact of organizational foundings (new establishments started by existing firms, generally as subsidiaries or branches) and individual foundings (independent new firms) on employment. Since organizational foundings are initiated by existing firms, it is reasonable to expect the characteristics of these establishments to be distinct from those of independent new firms started by people in the labor market. The resource-base of the parent firm can, for example, give an organizational founding a solid basis on which to build, while individual foundings lack any such easy access to resources. Further, access to resources has been shown to explain improved survivability and size (Tübke 2004; Brüderl et al. 1992). Given that organizational foundings make up a sizeable proportion of all foundings in The Netherlands (36\% in 2006), the overall economic impact of this group can be considerable.

The article now proceeds, in Section 2, to further develop the distinction between organizational foundings and individual foundings, particularly in relation to regional employment generation. Here, the time-lag model introduced by Fritsch and Mueller (2004) will also be explained in more detail. Section 3 then describes the data used and the empirical model. Section 4 presents results, and Section 5 draws conclusions.

\section{Background}

2.1 New firm formation and employment growth

Although employment is only one element of economic development, theories concerning the relationship between new firm formation and employment 
growth take inspiration from the possible influence of the former on economic development in the wider sense. In this, Schumpeter's (1912) explanation of the functions of entrepreneurship ${ }^{1}$ (as represented in new firms) is important; that is, by introducing new ideas, creating new products and production processes, developing organizational structures, and entering new markets, entrepreneurs challenge current economic conditions. Apart from entrepreneurship having a direct effect by raising the number of product solutions and the level of market development, there is also an indirect effect. Entrepreneurship forces existing actors, i.e., incumbent firms, to improve their efficiency. Existing firms need to adapt to the new standards set. Firms that are unable or unwilling to do so will lose their competitive advantage and eventually disappear. This process of "creative destruction" enhances regional productivity, regional competitiveness, and as a consequence, regional economic development. Apart from the replacement effect, Fritsch and Mueller (2004) see three additional effects of new firm formation on economic development. Firstly, innovative entry enhances the variety of products and product solutions. Secondly, breakthrough innovations by new firms can create new markets. Thirdly, the very threat of entry can be a sufficient stimulant for incumbent firms to improve efficiency. In short, given the introductory and innovative elements of entrepreneurship, a positive relationship between entrepreneurship and consequent economic growth is to be expected.

Schumpeter's model implies that the relationship between new firm formation and economic development takes shape over a few phases, or in other words, that there is a temporal dimension to the relationship. Fritsch and Mueller (2004) formalized a model to describe the temporal impact on employment development (Fig. 1).

The model describes three stages in the impact of new firms on regional employment development. Initially, new firms have a direct employment-generating effect (phase I). Even very small firms offer

\footnotetext{
1 This paper sees entrepreneurship and new firm formation, or founding, as two distinct processes. Entrepreneurship is the act of introducing innovative ideas either inside existing firms or in new firms. New firm formation is the start-up of a new business.
}

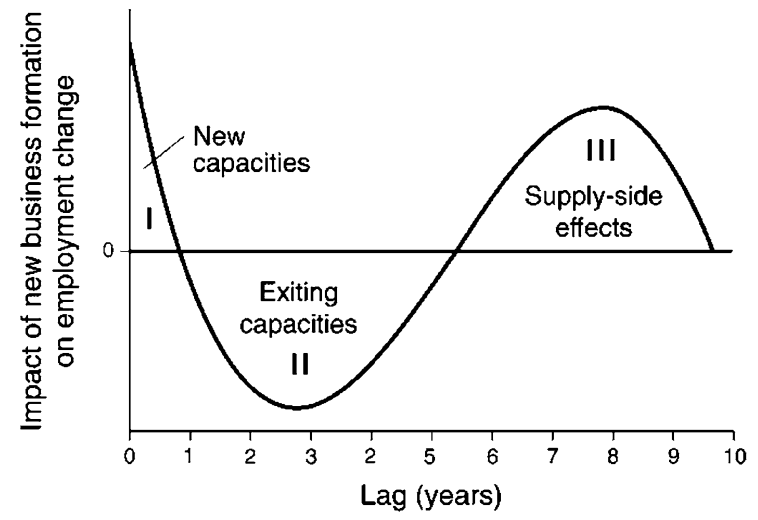

Fig. 1 Stylized model of the relationship between new firm formation and employment growth over time. Source: Fritsch and Mueller (2004)

employment to at least the founder of the firm. The combined effect of all new foundings may be substantial. In The Netherlands, for example, there have been approximately 50,000 new firms annually in recent years. Assuming that at least some of the jobs previously occupied by the founders will be filled by others, a direct increase in employment will result. After this initial stage, however, there may be negative effects on employment (phase II). Employment in incumbent firms becomes threatened by increased competition from the new firms. This phase mimics the Schumpeterian argument of creative destruction, involving the replacement of existing, less-efficient firms. In addition, many new firms will not survive the first years of operation (see, for example, Karlsson and Nyström 2003). Both effects could contribute to decreasing employment in this stage. After this stage, the effect turns positive again because of an overall beneficial effect on the regional economy (phase III). This is in line with the Schumpeterian idea of development through entrepreneurship: the overall efficiency in a region should have increased, leading to employment growth. Fritsch and Mueller (2004) capture this as supplyside effects. Eventually, the impact of the cohort of start-ups from the base year fades away. Empirical evidence for this wave-shaped relationship has been found for the UK (Mueller et al. 2008; van Stel and Storey 2004), Germany (Fritsch and Mueller 2004), Portugal (Baptista et al. 2008; Baptista and Preto this issue), Spain (Arauzo Carod et al. 2008), and The Netherlands (van Stel and Suddle 2008). The evidence clearly suggests that, in order to assess the 
relationship between new firm formation and employment generation, a longitudinal setting is essential.

\subsection{Organizational foundings and employment growth}

The model outlined above does not make a distinction between founding types. However, microlevel studies have shown that there are important performance differences between different types of foundings. Generally speaking, the background of a founding is an important determinant of later performance. Particularly relevant industry experience and previous start-up experience by the founder have positive influences on the performance of a new firm (Klepper and Simons 2000; Westhead et al. 2003). This implies that the wave model may have distinct shapes for different founding types. Based on these insights, one could also expect the backgrounds of foundings to have a distinct impact on regional employment generation. In the following discussion, how organizational foundings differ from individual foundings is considered as well as how this may affect the impact on employment in terms of the stylized model shown in Fig. 1.

The defining distinction between organizational and individual foundings is the influence of a parent firm. This has important consequences for the characteristics of organizational foundings. The decision process involved and the motives for opening a new subsidiary are the first aspects in which the influence of a parent firm is apparent. An individual founding can be regarded as a decision by an entrepreneur, or a group of entrepreneurs, with the goal of appropriating a business opportunity (Eckhardt and Shane 2003; Shane 2005). In contrast, Acs and Armington (2004) contend that organizational foundings are not so much based on the capitalization of entrepreneurial opportunities but, rather, on the strategic arguments of the parent firm. These arguments are often driven by the pursuit of economies of scale. Stam (2003) also finds, in The Netherlands, that new establishments that are part of multi-unit firms are only rarely based on the appropriation of entrepreneurial opportunities. More practical arguments, such as space restrictions and spatial market development, tend to be the important drivers of the decision to start a new establishment. Thus, individual foundings can be seen as appropriating entrepreneurial opportunities (Shane 2005), whereas organizational foundings are more often based on internal and strategic arguments of the parent company. In line with this argument, both Koster (2006) and Bosma et al. (2008) find distinct explanations for the regional patterns seen in individual foundings and organizational foundings. Bosma et al. (2008) show that agglomeration economies seem to encourage organizational foundings, whereas individual foundings are more frequent in regions with relatively large localization economies. ${ }^{2}$ This finding suggests that a multi-unit firm retains the knowledge-base of the company at its initial location (the headquarters) and uses the new establishment to penetrate new markets. In terms of the wave model, this implies that the positive supply effects (phase III) resulting from entrepreneurial activities by the founders may be less pronounced for organizational foundings.

A second important aspect in which the parent company has a clear role is in the founding's access to resources, and this will have an impact on performance. Given its inherent ties to a parent company, an organizational founding can be expected to have relatively easy access to the resources needed for production. The resource-base of the parent firm can, to some extent, be used in the start-up of the new establishment. Following the resource-based and resource-dependence theories of firm behavior, easy access to good-quality resources translates into better performance (Barney 1991; Penrose 1959). Organizational foundings can thus be expected to have, on average, better access to knowledge and other production resources, which will give them a competitive edge over other firms (Brüderl et al. 1992). In addition, using the active learning framework of Evans and Jovanovic (1989), it can be expected that existing organizations will be able to make a better judgement of production costs when entering a market. This knowledge can be used in the start-up of organizational foundings and, as a result, the probability of operating profitably is higher for this type of firm. The anticipated high performance levels of organizational foundings have been empirically

\footnotetext{
2 This is in line with the knowledge spillover theory of entrepreneurship (Acs et al. 2006), which assumes that new firms (individual foundings) are based on business opportunities ignored by existing firms.
} 
tested, mainly in terms of survival and firm size. These empirical studies only partly support the proposed positive relationship between having a background in a parent firm and performance. Audretsch and Mahmood (1994) find a clear and positive effect of organizational background on survival, and Tübke (2004) shows that affiliated new establishments are generally larger than unaffiliated ones. Koster (2006) and Brüderl et al. (1992), however, did not find elevated levels of survival for organizational foundings. They argue that the lack of independence may compromise innovative capabilities and that this could constrain the performance of the establishments. Koster (2006) also reported a relatively high propensity for organizational foundings to hire employees, thus corroborating Tübke's findings.

The solid resource-base of organizational foundings has two implications for the wave model. Firstly, one sees that the initial size of establishments with a background in a parent firm is relatively large, suggesting that the immediate impact of organizational foundings may also be relatively large (phase I). Secondly, the competition effects (phase II) of organizational foundings may be affected. There are two effects. On the one hand, the high survival rate of organizational foundings may reduce (or delay) the loss of employment resulting from start-ups closing. On the other hand, the resources and knowledge available to organizational foundings may prove an important competitive advantage over other firms (Evans and Jovanovic 1989), hindering employment growth elsewhere. Interestingly, Acs and Mueller (2008) use the same argument to explain regional employment growth (rather than decline) as a result of increased competition in the region. They argue that the higher survival propensity of larger firms forces incumbent firms to improve performance which, in turn, will lead to an increase in regional employment. The empirical evidence in their paper supports this view, as large firms were found to have a greater impact on regional employment growth than were small firms. Relating this to the four functions of new firm formation, as introduced earlier, Acs and Mueller (2008) emphasize the enhanced efficiency due to competition over the selection effect of competition. Despite the empirical evidence supporting the positive effects of competition, it is still too early to rule out the selection effect since the effects become apparent in distinct phases of the stylized model (Fig. 1). The competition effect is linked to the second phase, whereas enhanced efficiency is a supply-side effect that is seen in the third phase. Thus, both effects may be important in theoretically explaining the pattern of employment generation over time. The net outcome of both effects remains an issue to explore empirically.

\section{Data and model}

\subsection{Data}

Data on the start-up of new companies were obtained from the business register maintained by the Dutch Chambers of Commerce (KvK). Upon compulsory registration in the business register, new establishments are classified according to their organizational background. A distinction is made between genuinely new establishments (individual foundings) and the founding of establishments that are part of a larger organization (organizational foundings). An organizational founding is defined by the $\mathrm{KvK}$ as "the start of a new economic activity by an existing company" (Chambers of Commerce, annually). Organizational foundings include franchises, new outlets, new offices, and plants started by incumbent firms. Although the Chambers of Commerce annually publish the dynamics of the business register, a longitudinal account of individual firms is not readily available. EIM business and policy research, however, do provide an online database of firm dynamics in The Netherlands. This dataset is based on KvK data and covers firm dynamics in The Netherlands from 1988 to 2007. On average, 50,496 individual foundings were registered annually in the period studied (19932005). The peak was in 2004, with 63,733 new individual foundings. Organizational foundings are less common, typically being $50-60 \%$ of the number of individual foundings per year. On average, over the study period, there were 28,594 new organizational foundings annually. The peak year was again 2004, when 37,144 new organizational foundings were registered.

The data available are on a regional basis and, as we want to make regional comparisons, the number of foundings needs to be corrected for the size of the region. In order to facilitate comparison of the 
relative impacts of both types of foundings, the labor market approach is used to standardize the number of both individual and organizational foundings. The founding rates are calculated by dividing the number of foundings by the potential labor market population (inhabitants between 15 and 65 years) in a region. However, it should be pointed out that, since organizational foundings are the result of actions by existing firms, it would, theoretically, be more appropriate to express organizational founding rates using the ecological approach (Koster 2007; Bosma et al. 2008). Then, organizational foundings would be related to the number of existing firms in a region, rather than to the labor market population. Unfortunately, this would make statistical comparison of the two rates problematic and, as the goal is to assess the impact of both types of founding simultaneously, the rates have been normalized using the same, labor market method.

Data concerning foundings have been extracted from the EIM online database. Any other data required have been extracted from publicly available regional databases provided by Statistics Netherlands (the official governmental statistical organization). This somewhat hampered the analysis, as consistent employment data are only available for the period 1993-2005. The analyses have been conducted for 40 NUTS-3 regions. ${ }^{3}$

\subsection{Modeling issues}

The significant issue in the theoretical model as described in Section 2 is the idea that new firm formation does not only have an immediate effect on employment, but that the effect continues over time and changes as illustrated in Fig. 1. Empirically, delayed effects can be incorporated in a regression analysis by including time-lagged start-up rates. However, start-up rates are fairly consistent over time in terms of both level and regional distribution (Fritsch and Mueller 2007). This means that the timelagged start-up rates would be highly correlated, leading to multicollinearity in the model. In order to overcome this, the Almon lag method is used. This

\footnotetext{
${ }^{3}$ In The Netherlands, NUTS-3 regions were defined as functional units in the 1960s. They regularly serve as regional divisions when studying economic phenomena in The Netherlands.
}

method restricts the coefficients of the lagged start-up rates in such a way that they lie on a polynomial that formally describes the correlation between the yearly founding rates. By restricting the coefficients in this way, a more efficient model that avoids multicollinearity problems is formulated. More detailed technical explanations of this method can be found in van Stel and Storey (2004) and Fritsch and Mueller (2004). A critical issue in applying the Almon method is determining the appropriate functional form and order of the polynomial to be used in restricting the coefficients of the start-up rates. Based on the theoretical model illustrated in Fig. 1, a thirdorder function seems likely to be the most appropriate. A number of similar studies have indeed found a third-order function to be the most satisfactory (Fritsch and Mueller 2004; van Stel and Suddle 2008). In some cases, however, fourth-order functions have been found to fit the data significantly better or at least equally well (Baptista et al. 2007; van Stel and Suddle 2008). Although other functional forms are possible, the existing studies using Almon polynomials suggest that third- or fourth-order functions provide the most satisfactory results. Following these earlier conclusions, the present analysis will focus on third- and fourth-order Almon polynomials. ${ }^{4}$

Apart from the functional form of the Almon polynomial, the maximum lag time also needs to be determined. This is an important decision because increasing the maximum lag decreases the number of observations in the model. In the earlier empirical studies considered, the lag length was a minimum of 7 years (Arauzo Carod et al. 2008) and a maximum of 12 years (Fritsch and Mueller 2004). Given the length of the period covered by our data, and because only 40 regions are included in the present analysis, the maximum lag period was set to 8 years, giving us 200 time-region observations. ${ }^{5}$

In the analysis, the 2-year average percentage change in employment is selected as the dependent variable (following Mueller et al. 2008; Acs and Armington 2004; Fölster 2000). This allows for structural differences between regions to take shape

\footnotetext{
${ }^{4}$ Second- and fifth-order functions were also tested, but their performance was significantly worse.

5 Decreasing the maximum lag interval, and so increasing the number of observations, did not result in results significantly different from those presented in the next section.
} 
and evens out yearly fluctuations. Finally, two control variables were added to the model. Population density is used as a catch-all variable of regional structure, and the lagged dependent variable is added in order to overcome possible problems with Granger causality. Including this term is particularly relevant in the current analysis, as parent firms could be expected to start subsidiaries because they are in search of market expansion. In such a situation, employment, as a measure of economic development, may be leading organizational founding rates rather than the other way around. Including a lagged dependent variable, however, could induce a Nickell bias caused by a correlation between the average of the lagged dependent variables and the error term (Nickell 1981), violating an assumption for a leastsquares (LS) approach. A generalized method of moments (GMM) estimation has been performed to counteract this problem (following Carree 2002). This procedure serves as a robustness check of the Almon models.

The models were checked for spatial dependence in both the dependent variable and the error terms. Moran's I statistics remained within tolerance levels and no spatial dependencies were detected. This is not surprising, as the regions are fairly large and, moreover, they were constituted in such a way that they represented functional regions of The Netherlands. Both characteristics minimize spillovers, which makes spatial dependence less likely.

\section{Results}

The empirical analysis was carried out in two steps. In the first step, the effects of both founding types on employment were assessed separately. In the second step, the combined effect of organizational and individual foundings was assessed. Table 1 shows the results, for individual foundings, of the LS regression with White diagonal standard errors and covariance (following van Stel and Suddle 2008). Table 2 shows the equivalent results for organizational foundings. The first column of results in both tables is for the unrestricted model in which the lagged start-up rates have been included but without any correction for collinearity. The next column shows the results from the restricted model in which an Almon polynomial is used to describe the correlation form of the lagged variables. The final column contains the restricted coefficients of the lagged start-up rates that result from the restricted model.

In the analysis, all models are based on Almon fourth-order polynomials, as these were found to outperform other polynomial orders. In the full model (Table 3), the log-likelihood of the Almon fourthorder polynomial model is -448.91 , compared with -467.28 for the third-order estimation (Appendix I). Using a log-likelihood ratio test with two degrees of freedom, this difference was found to be significant at the $1 \%$ level. ${ }^{6}$ This finding is in contrast with another study in The Netherlands by van Stel and Suddle (2008), who found a third-order function to be preferable. However, they used sector-adjusted start-up rates, which were not available for the present study, and also considered a slightly different time period. Further, in their study, the fourth-order function was not significantly worse than the third order, suggesting that a fourth-order approximation would have been a viable option. The fourth-order function is, in our situation, also preferred from a theoretical point of view as it can accommodate the expectation that individual start-ups generate a supply effect that has a positive impact on both a regional economy and on employment generation (Fig. 2). Conversely, restricted coefficients based on estimations using a third-order polynomial will not show this expected pattern (Appendix I). ${ }^{7}$

Table 1 provides the findings from the analysis regarding the effect of individual start-up rates on employment generation. The analysis is similar to previous analyses and the outcomes can be compared with existing evidence. Theoretically, a wave pattern is expected, and Fig. 2, which graphically represents the restricted coefficients, does indeed show the expected wave pattern for individual foundings, thus corroborating earlier evidence. Also the unrestricted coefficients suggest a wave pattern (Appendix II),

\footnotetext{
${ }^{6}$ The test statistic is $2(-448.91+467.28)=36.74$ with $\mathrm{df}=2$. This is significant at the $1 \%$ confidence level (critical value 9.2).

${ }^{7}$ For the individual models (Tables 1, 2), the log-likelihood tests comparing third- and fourth-order Almon curves are not presented herein. They convey the same information as the tests for the full model. The fourth-order models are significantly better, and the curves are U-shaped (as shown for the full model in Appendix I).
} 
Table 1 Impact of individual foundings on employment generation
Ordinary least-squares (OLS) estimations with White standard errors and covariance [standard error (SE) in parentheses]

Significance levels: $* * 1 \%$; $* 5 \%$

\begin{tabular}{|c|c|c|c|c|}
\hline & \multicolumn{4}{|c|}{ Dependent variable: 2-year employment change } \\
\hline & Unrestricted & & $\begin{array}{l}\text { Almon polynomial } \\
\text { (fourth order) }\end{array}$ & $\begin{array}{l}\text { Restricted } \\
\text { coefficients }\end{array}$ \\
\hline Constant & $\begin{array}{l}0.24 \\
(1.20)\end{array}$ & & $\begin{array}{l}-0.28 \\
(1.22)\end{array}$ & \\
\hline Population density & $\begin{array}{l}-0.09 \\
(0.03)^{* *}\end{array}$ & & $\begin{array}{l}-0.09 \\
(0.03)^{* *}\end{array}$ & \\
\hline Employment change $t-2$ & $\begin{array}{l}0.24 \\
(0.07)^{* *}\end{array}$ & & $\begin{array}{l}0.23 \\
(0.06)^{* *}\end{array}$ & \\
\hline Individual start-up rate $t-0$ & $\begin{array}{l}-1.29 \\
(0.36)^{* *}\end{array}$ & $\mathrm{C} 0$ & $\begin{array}{l}-0.78 \\
(0.12)^{* *}\end{array}$ & $\begin{array}{l}-0.57 \\
(0.30)\end{array}$ \\
\hline Individual start-up rate $t-1$ & $\begin{array}{l}1.92 \\
(0.39) * *\end{array}$ & $\mathrm{C} 1$ & $\begin{array}{l}-0.08 \\
(0.07)\end{array}$ & $\begin{array}{l}0.85 \\
(0.16)\end{array}$ \\
\hline Individual start-up rate $t-2$ & $\begin{array}{l}0.00 \\
(0.47)\end{array}$ & $\mathrm{C} 2$ & $\begin{array}{l}0.38 \\
(0.06)^{* *}\end{array}$ & $\begin{array}{l}0.47 \\
(0.16)\end{array}$ \\
\hline Individual start-up rate $t-3$ & $\begin{array}{l}-1.04 \\
(0.45)^{*}\end{array}$ & $\mathrm{C} 3$ & $\begin{array}{l}0.01 \\
(0.06)\end{array}$ & $\begin{array}{l}-0.36 \\
(0.10)\end{array}$ \\
\hline Individual start-up rate $t-4$ & $\begin{array}{l}0.03 \\
(0.45)\end{array}$ & $\mathrm{C} 4$ & $\begin{array}{l}-0.02 \\
(0.00)^{* *}\end{array}$ & $\begin{array}{l}-0.78 \\
(0.12)\end{array}$ \\
\hline Individual start-up rate $t-5$ & $\begin{array}{l}-0.38 \\
(0.32)\end{array}$ & & & $\begin{array}{l}-0.49 \\
(0.10)\end{array}$ \\
\hline Individual start-up rate $t-6$ & $\begin{array}{l}0.36 \\
(0.28)\end{array}$ & & & $\begin{array}{l}0.30 \\
(0.11)\end{array}$ \\
\hline Individual start-up rate $t-7$ & $\begin{array}{l}0.30 \\
(0.28)\end{array}$ & & & $\begin{array}{l}0.86 \\
(0.15)\end{array}$ \\
\hline Individual start-up rate $t-8$ & $\begin{array}{l}0.18 \\
(0.36)\end{array}$ & & & $\begin{array}{l}-0.09 \\
(0.16)\end{array}$ \\
\hline$R$-square & 0.53 & & 0.50 & \\
\hline Log-likelihood & -448.37 & & -455.27 & \\
\hline$N$ & 200 & & 200 & \\
\hline
\end{tabular}

albeit less pronounced than the smoothed coefficients as presented in Fig. 2. The exception is for the first year, which has a theoretically unexpected negative sign. Van Stel and Suddle (2008) also found the same unexpected initial effect for The Netherlands. A possible explanation is that self-employment is measured separately from employment in The Netherlands. So, an employed person leaving their job to start-up a new firm reduces the number of employed in favor of the number of self-employed. As most new firms are started by people leaving paid employment, this effect may be sizeable. The negative coefficient would suggest that the effect of this on the total number of employees is not compensated for by new staff employed by the new establishments, which is perhaps not surprising as new firms generally start very small. In addition, causality is a potential problem in the first year, as cause and effect are measured at the same time. This may lead to confounding results. Indeed, using a third-order Almon curve results in a Ushaped relationship with a positive immediate effect of individual start-ups (as shown for the full model in Appendix I).

In succeeding years, the expected pattern is followed to the letter. The initial period of a direct effect lasts for 2 years, indicating that it cannot be solely explained by the initial employment-generating effect at start-up: it seems that registered new firms need some time to reach their anticipated initial size. The direct-effect period is then followed by 3 years in which the competition effect dominates. Following this, the anticipated supply effect is found. 
Table 2 Impact of organizational foundings on employment generation
OLS estimations with White standard errors and covariance (SE in parentheses)

Significance levels: ** $1 \%$; * $5 \% ;{ }^{\dagger} 10 \%$

\begin{tabular}{|c|c|c|c|c|}
\hline & \multicolumn{4}{|c|}{ Dependent variable: 2-year employment change } \\
\hline & Unrestricted & & $\begin{array}{l}\text { Almon polynomial } \\
\text { (fourth order) }\end{array}$ & $\begin{array}{l}\text { Restricted } \\
\text { coefficients }\end{array}$ \\
\hline Constant & $\begin{array}{l}-1.46 \\
(0.64)^{*}\end{array}$ & & $\begin{array}{l}-1.45 \\
(0.64)^{*}\end{array}$ & \\
\hline Population density & $\begin{array}{l}-0.07 \\
(0.04)^{\dagger}\end{array}$ & & $\begin{array}{l}-0.07 \\
(0.04)^{\dagger}\end{array}$ & \\
\hline Employment change $t-2$ & $\begin{array}{l}0.37 \\
(0.05)^{* *}\end{array}$ & & $\begin{array}{l}0.37 \\
(0.05)^{* *}\end{array}$ & \\
\hline Organizational start-up rate $t-0$ & $\begin{array}{l}0.20 \\
(0.51)\end{array}$ & D0 & $\begin{array}{l}-0.51 \\
(0.22)^{*}\end{array}$ & $\begin{array}{l}0.35 \\
(0.42)\end{array}$ \\
\hline Organizational start-up rate $t-1$ & $\begin{array}{l}1.00 \\
(0.58)^{\dagger}\end{array}$ & D1 & $\begin{array}{l}-0.08 \\
(0.12)\end{array}$ & $\begin{array}{l}0.65 \\
(0.26)\end{array}$ \\
\hline Organizational start-up rate $t-2$ & $\begin{array}{l}-0.15 \\
(0.54)\end{array}$ & D2 & $\begin{array}{l}0.19 \\
(0.11)^{\dagger}\end{array}$ & $\begin{array}{l}0.26 \\
(0.24)\end{array}$ \\
\hline Organizational start-up rate $t-3$ & $\begin{array}{l}-0.12 \\
(0.47)\end{array}$ & D3 & $\begin{array}{l}0.00 \\
(0.01)\end{array}$ & $\begin{array}{l}-0.25 \\
(0.17)\end{array}$ \\
\hline Organizational start-up rate $t-4$ & $\begin{array}{l}-0.24 \\
(0.50)\end{array}$ & D4 & $\begin{array}{l}-0.01 \\
(0.01)\end{array}$ & $\begin{array}{l}-0.51 \\
(0.22)\end{array}$ \\
\hline Organizational start-up rate $t-5$ & $\begin{array}{l}-0.72 \\
(0.44)\end{array}$ & & & $\begin{array}{l}-0.39 \\
(0.19)\end{array}$ \\
\hline Organizational start-up rate $t-6$ & $\begin{array}{l}0.04 \\
(0.38)\end{array}$ & & & $\begin{array}{l}-0.03 \\
(0.21)\end{array}$ \\
\hline Organizational start-up rate $t-7$ & $\begin{array}{l}0.24 \\
(0.41)\end{array}$ & & & $\begin{array}{l}0.25 \\
(0.26)\end{array}$ \\
\hline Organizational start-up rate $t-8$ & $\begin{array}{l}-0.05 \\
(0.34)\end{array}$ & & & $\begin{array}{l}-0.13 \\
(0.32)\end{array}$ \\
\hline$R$-square & 0.40 & & 0.40 & \\
\hline Log-likelihood & -472.99 & & -473.80 & \\
\hline$N$ & 200 & & 200 & \\
\hline
\end{tabular}

In our study, the impact of start-ups fades away after 8 years. The overall effect of start-ups can be calculated by summing the restricted coefficients. For individual foundings, the overall effect is positive (sum is 0.19), which is in line with the general assumption that new firm formation has a positive effect on employment generation.

The effect of the organizational start-up rate on employment has a similar pattern over time as that of individual foundings (Table 2; Fig. 2). There is an initial positive effect representing the new employment generated in the starting up of new establishments by existing firms. This positive direct effect is in line with the idea that the solid resource-base of the parent firm allows subsidiaries to hire employees immediately. As a result, new subsidiaries have relatively many employees compared with other foundings (Tübke 2004). In addition, the effect of organizational foundings is not confused by any data caveats regarding the counting of self-employed individuals, since organizational foundings do not have an impact on the number of self-employed. Apart from the instant positive initial effect, the shape of the curve is similar to that of individual foundings. The similarity in the curves raises the question of whether both founding types represent the same underlying variable, perhaps a regional entrepreneurial culture, for example. However, the correlation between the two founding rates is only 0.23 , suggesting that the rates do indeed measure distinct phenomena. In addition, both the spatial patterns and the explanation for these patterns have been shown to 
Table 3 Impact of organizational and individual foundings on employment generation
OLS estimations with White standard errors and covariance (SE in parentheses)

Significance levels: ** $1 \%$; * $5 \%{ }^{\dagger} 10 \%$

\begin{tabular}{|c|c|c|c|c|}
\hline & \multicolumn{4}{|c|}{ Dependent variable: 2-year employment change } \\
\hline & Unrestricted & & $\begin{array}{l}\text { Almon correction } \\
\text { (fourth order) }\end{array}$ & $\begin{array}{l}\text { Restricted } \\
\text { coefficients }\end{array}$ \\
\hline Constant & $\begin{array}{l}0.16 \\
(1.23)\end{array}$ & & $\begin{array}{l}-0.29 \\
(1.22)\end{array}$ & \\
\hline Population density & $\begin{array}{l}-0.10 \\
(0.04)^{* *}\end{array}$ & & $\begin{array}{l}-0.09 \\
(0.04)^{*}\end{array}$ & \\
\hline Employment change $t-2$ & $\begin{array}{l}0.23 \\
(0.07)^{* *}\end{array}$ & & $\begin{array}{l}0.23 \\
(0.07)^{* *}\end{array}$ & \\
\hline Individual start-up rate $t-0$ & $\begin{array}{l}-1.34 \\
(0.43)^{* *}\end{array}$ & $\mathrm{C} 0$ & $\begin{array}{l}-0.85 \\
(0.12)^{* *}\end{array}$ & $\begin{array}{l}-0.59 \\
(0.34)\end{array}$ \\
\hline Individual start-up rate $t-1$ & $\begin{array}{l}1.87 \\
(0.42)^{* *}\end{array}$ & $\mathrm{C} 1$ & $\begin{array}{l}-0.11 \\
(0.08)\end{array}$ & $\begin{array}{l}0.87 \\
(0.17)\end{array}$ \\
\hline Individual start-up rate $t-2$ & $\begin{array}{l}0.09 \\
(0.57)\end{array}$ & $\mathrm{C} 2$ & $\begin{array}{l}0.39 \\
(0.06)^{* *}\end{array}$ & $\begin{array}{l}0.47 \\
(0.17)\end{array}$ \\
\hline Individual start-up rate $t-3$ & $\begin{array}{l}-1.06 \\
(0.53)^{*}\end{array}$ & $\mathrm{C} 3$ & $\begin{array}{l}0.01 \\
(0.01)\end{array}$ & $\begin{array}{l}-0.39 \\
(0.11)\end{array}$ \\
\hline Individual start-up rate $t-4$ & $\begin{array}{l}-0.16 \\
(0.46)\end{array}$ & $\mathrm{C} 4$ & $\begin{array}{l}-0.02 \\
(0.00)^{* *}\end{array}$ & $\begin{array}{l}-0.85 \\
(0.12)\end{array}$ \\
\hline Individual start-up rate $t-5$ & $\begin{array}{l}-0.39 \\
(0.33)\end{array}$ & & & $\begin{array}{l}-0.58 \\
(0.11)\end{array}$ \\
\hline Individual start-up rate $t-6$ & $\begin{array}{l}0.25 \\
(0.30)\end{array}$ & & & $\begin{array}{l}0.22 \\
(0.13)\end{array}$ \\
\hline Individual start-up rate $t-7$ & $\begin{array}{l}0.26 \\
(0.33)\end{array}$ & & & $\begin{array}{l}0.81 \\
(0.16)\end{array}$ \\
\hline Individual start-up rate $t-8$ & $\begin{array}{l}0.26 \\
(0.22)\end{array}$ & & & $\begin{array}{l}-0.06 \\
(0.17)\end{array}$ \\
\hline Organizational start-up rate $t-0$ & $\begin{array}{l}0.89 \\
(0.54)^{\dagger}\end{array}$ & D0 & $\begin{array}{l}-0.42 \\
(0.19)^{*}\end{array}$ & $\begin{array}{l}0.83 \\
(0.45)\end{array}$ \\
\hline Organizational start-up rate $t-1$ & $\begin{array}{l}0.21 \\
(0.56)\end{array}$ & D1 & $\begin{array}{l}-0.09 \\
(0.13)\end{array}$ & $\begin{array}{l}0.46 \\
(0.21)\end{array}$ \\
\hline Organizational start-up rate $t-2$ & $\begin{array}{l}-0.02 \\
(0.54)\end{array}$ & D2 & $\begin{array}{l}0.09 \\
(0.09)\end{array}$ & $\begin{array}{l}0.06 \\
(0.22)\end{array}$ \\
\hline Organizational start-up rate $t-3$ & $\begin{array}{l}0.31 \\
(0.49)\end{array}$ & D3 & $\begin{array}{l}0.00 \\
(0.01)\end{array}$ & $\begin{array}{l}-0.25 \\
(0.19)\end{array}$ \\
\hline Organizational start-up rate $t-4$ & $\begin{array}{l}-0.63 \\
(0.49)\end{array}$ & D4 & $\begin{array}{l}-0.00 \\
(0.01)\end{array}$ & $\begin{array}{l}-0.42 \\
(0.19)\end{array}$ \\
\hline Organizational start-up rate $t-5$ & $\begin{array}{l}-0.56 \\
(0.43)\end{array}$ & & & $\begin{array}{l}-0.42 \\
(0.16)\end{array}$ \\
\hline Organizational start-up rate $t-6$ & $\begin{array}{l}0.03 \\
(0.43)\end{array}$ & & & $\begin{array}{l}-0.26 \\
(0.21)\end{array}$ \\
\hline Organizational start-up rate $t-7$ & $\begin{array}{l}0.15 \\
(0.41)\end{array}$ & & & $\begin{array}{l}0.03 \\
(0.25)\end{array}$ \\
\hline Organizational start-up rate $t-8$ & $\begin{array}{l}0.11 \\
(0.33)\end{array}$ & & & $\begin{array}{l}0.34 \\
(0.28)\end{array}$ \\
\hline$R$-square & 0.56 & & 0.53 & \\
\hline Log-likelihood & -442.33 & & -448.91 & \\
\hline$N$ & 200 & & 200 & \\
\hline
\end{tabular}




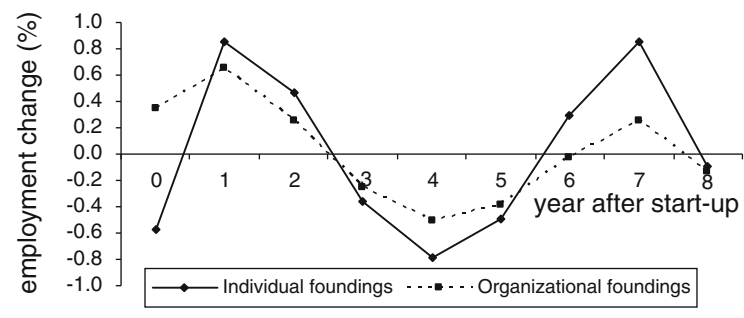

Fig. 2 Restricted coefficients of individual models

be distinct for the two types (Bosma et al. 2008; Koster 2006). Overall, the accumulated effect of organizational start-ups is also positive (sum of restricted coefficients is 0.20 ). This suggests that, despite the distinct features of organizational foundings, the effect on employment of both organizational foundings and individual foundings is similar.

Although both the patterns and the sum of the coefficients are similar for both types of founding, the strength of the relationship between founding rates and employment generation is weaker for organizational foundings. ${ }^{8}$ Tables 1 and 2 show that the restricted coefficients and their $t$ values are lower for organizational foundings throughout the whole period, with the exception of the first year. ${ }^{9}$ This finding is consistent with the argument that organizational foundings initially tend to be larger than individual foundings because of their solid resource-base, and hence they have a larger direct effect. However, following startup, their closeness to the parent company can hold back their innovativeness, mitigating their effect on the process of regional creative destruction, and because of this, individual foundings appear to be more important for employment generation in the longer term. By assessing the effects of the founding types simultaneously, this issue can be further explored.

In the simultaneous mode ${ }^{10}$ (Table 3), the effect of the regional individual start-up rate on employment is similar to its effect in the separate model (Table 1).

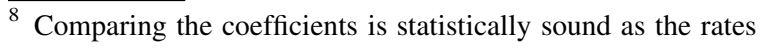
are calculated in the same way.

9 The $t$ values of the coefficients for the organizational start-up rates were also consistently lower (not reported in this paper).

10 Appendix III presents the results for the simultaneous model using a GMM approach, aimed at counteracting Nickell bias in the Almon procedure. The results are similar: individual start-ups follow the wave pattern, including a positive effect after 6 years; organizational start-ups have a mainly short-term positive effect and only a very small effect later on.
}

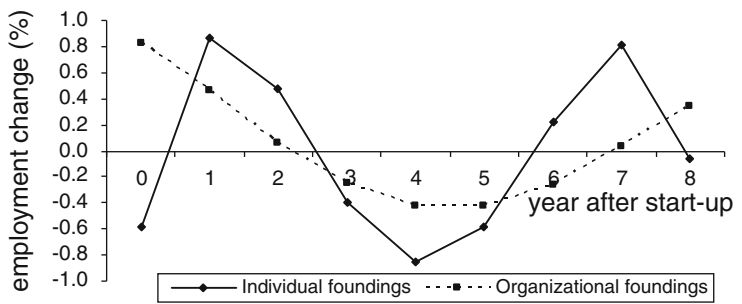

Fig. 3 Restricted coefficients of simultaneous model

The wave pattern is reproduced (compare Figs. 2 and 3 ), and the $t$ values of the restricted coefficients are high, suggesting that individual start-ups are important in explaining employment development, which is in line with existing studies and expectations. The results for organizational start-ups are, however, different. The shape of the pattern has changed (compare Figs. 2 and 3), and the explanatory power of organizational foundings has almost completely evaporated. There is still an important short-term positive direct effect but, after 2 years, this effect has all but disappeared and the coefficients remain close to zero ( $t$ values are low after 2 years). This further substantiates the finding from the first analysis (Table 2) that the effect of organizational foundings is largely short term. This, to an extent, contradicts resource-based theory because, on the firm level, this argues that firms with good access to resources (such as organizational foundings) will outperform firms with a smaller initial resource-base. The analysis shows that, at least on the regional level, organizational foundings do indeed have a large initial effect, which can be ascribed to their good resource-base, but that regional growth in later years cannot be credited to organizational foundings. This suggests that organizational foundings have little impact in terms of introducing new innovative combinations to a region. Bosma et al. (2008) suggest the same in that they see the knowledge-base of a multi-unit firm typically remaining at headquarters, and only to a small extent being transported to new establishments. In addition, given the well-endowed start that organizational foundings typically have, there may be less incentive to innovate, which could limit future development (Weterings and Koster 2007).

The lack of any long-term effect of organizational foundings, once one has controlled for individual foundings, is at odds with the conclusion of Acs and Mueller (2008), who found that large firms were the 
more important in stimulating employment growth, including over the longer term. They argue that the size of a firm is a reflection of its resource-base and that larger firms are, consequently, more competitive, which stimulates overall regional employment development. In the present study, access to a resourcebase was operationalized along the lines of having organizational ties with a parent company. This leads to a much lower long-term positive effect of wellendowed foundings (organizational foundings) on employment generation. In interpreting the contrasting conclusions of the two studies, one should not overlook their very different contexts. Acs and Mueller studied metropolitan areas in the USA, whereas our study covers the whole of The Netherlands, including many rural areas. Fritsch and Schroeter (this issue) show that urban areas generally profit more from new firm formation than do rural areas, and this could go some way to explaining the low impact of organizational foundings in this study.

The overall effect on employment generation (the sum of the restricted coefficients) for the two founding types is positive for organizational startups $(0.38)$ but negative for individual ones $(-0.11)$. The negative effect of individual start-ups is unexpected, but it can be accounted for by recalling that an important factor in the strongly negative coefficient for the first year is the fact that self-employed people are not included in the employment statistics used in this analysis. If one excludes the first-year effect, individual start-ups have a positive overall effect on employment. Also, if one was only to include those restricted coefficients that were statistically significant in the summations, then individual foundings would have a positive overall effect.

An alternative explanation for the negative effect could be that the impact of individual start-ups is not so much visible in the generation of employment, but rather in the creation of new combinations and business opportunities in a region. Organizational foundings can then reap the benefits of this work by exploiting the newly created regional capacities. As organizational foundings can compete on scale, this may be reflected in employment generation, particularly in the short term. In this scenario, individual start-ups, in a sense, pave the way for organizational start-ups. If this is a valid argument, then there are two empirical implications. Firstly, the economic effect of individual start-up rate should not only be considered in terms of employment generation, but also in terms of other indicators such as productivity and perhaps even measures of innovation. The hypothesis is that individual start-ups have a positive effect on regional productivity, whereas the effect of organizational foundings is primarily on employment generation. Secondly, the argument suggests that the lagged individual start-up rates should have a positive effect in explaining organizational founding rates. This can be tested empirically, although this is complicated by the reciprocity of the relationship: It has been shown elsewhere that new subsidiaries can also create opportunities for other entrepreneurs (Acs and Armington 2004), for example, as suppliers of the new establishments. This suggests a complex interplay between the two types of founding and, given their distinct impacts on employment generation, it would be fruitful to further explore this interplay in other studies.

\section{Conclusions and discussion}

Organizational foundings and individual foundings have distinct impacts on regional employment generation. The impact of individual foundings on employment follows a typical wave-like pattern, with an initial employment-generating effect followed by a negative effect that can be ascribed to increased competition for the incumbents. Finally, individual foundings have an entrepreneurial supply effect that positively influences the regional employment level. This pattern is in line with previous empirical findings in several European countries (Fritsch 2008). This theoretical model, however, is not applicable to organizational foundings. Organizational foundings have a positive direct effect on regional employment, but this rather rapidly tails off to a nonsignificant effect close to zero. The hypothesized entrepreneurial supply effect that results in an overall improvement in a region's economic structure is not found for organizational foundings. From this it can be concluded that individual foundings may be the more important for the long-term development of a regional economy. This result concurs with the idea that individual foundings represent a type of founding that is based on the recognition of business ideas, whereas organizational foundings are based on internal, practical considerations associated with firm 
growth. While the latter may indeed lead to a direct positive employment effect for the receiving region, it appears less important in terms of its structural development.

The distinct effects of the two founding types indicate that not only the level but also the types of new firm formation are important variables in explaining regional economic development, and that it is even possible to have the wrong kind of new firm formation in terms of employment generation (Davidson and Ekelund 1994). This is an important finding in terms of policy. The results suggest that too strong a focus on attracting new establishments from existing firms may jeopardize long-term economic growth. Although attracting plants from existing firms is an oft-used policy strategy, particularly in the peripheral parts of The Netherlands, focusing on stimulating entrepreneurship in the region may be more beneficial. Organizational foundings have a predominantly short-term effect, whereas individual foundings are also important over the longer term. In particular, entrepreneurial recombination of existing resources, reflected in the positive supply effect, is important for rejuvenating a regional economy. As such, it is an important condition for long-term economic development (Frenken et al. 2004). Furthermore, the creation of new opportunities by new firms may attract organizational foundings to the region. This argument needs further empirical substantiation, however. The exact relationship between individual foundings and organizational foundings is therefore seen as an important issue for further research. A related avenue would be to explore the impact of the type of new firm formation on other indicators of economic development. The supply-side argument relates to economic development in general terms and not solely to employment generation. If, indeed, individual start-ups are important for rejuvenating regional economies, and if organizational foundings are a response to this, then this effect should be more apparent in other indicators reflecting innovation, added value, and productivity.

While acknowledging that different types of foundings have different impacts on economic development, it must also be acknowledged that the division into founding groups remains an issue for debate. Foundings can differ in terms of many characteristics, making it difficult to choose a sensible theoretical distinction. From a theoretical point of view, it may be preferable to distinguish between founding types on the basis of their access to resources and knowledge, for example, by assessing resource transfer from a parent firm (as argued in Koster 2006). Unfortunately, such a strategy is not feasible in the context of regional studies based on large datasets. As a result, studies have to rely on measurable features of foundings, such as organizational background, sector or size, as done by Acs and Mueller (2008). However, to date, little development has gone into the theoretical implications of these distinctions.

The results also show that it is important to use a longitudinal framework in assessing the impact of founding types on employment generation. It takes a few years for the distinct impacts of organizational and individual foundings to become apparent. Using a cross-sectional approach could lead to the false inference that organizational foundings are more important for employment generation than are individual foundings. However, applying a longitudinal setting is not without problems. While the theoretical model backing the use of Almon curves seems sound, the empirical findings, of this and other studies, indicate that the specification of the model is sensitive to the space and time periods included. As a result, the specification of the Almon curves differs for different studies. This stresses the importance of studying the stability of the relationship between foundings and economic development: how do place, time, and type of founding influence the relationship between new firm formation and regional economic development?

In conclusion, this study provides further evidence for the view that individual foundings have a positive direct effect on employment, followed by a negative effect resulting from competition, which is then followed by a positive effect that can be attributed to an improvement in the quality of the supply side of the economy. The study also shows that this pattern does not necessarily apply to all types of founding: organizational foundings do have a positive direct effect, but do not demonstrate improved supply effects at a later stage. This suggests that, for longterm economic development, individual start-ups are the most important type of founding. 
Acknowledgments I would like to thank the anonymous referees, participants of the 2007 Uddevalla conference, and Michael Fritsch for valuable comments on earlier drafts. Part of this study was conducted at the Jönköping International Business Institute, Sweden.

Open Access This article is distributed under the terms of the Creative Commons Attribution Noncommercial License which permits any noncommercial use, distribution, and reproduction in any medium, provided the original author(s) and source are credited.

\section{Appendix I}

See Table 4 and Fig. 4.
Table 4 Model based on third-order Almon function

\begin{tabular}{|c|c|c|c|}
\hline & \multicolumn{3}{|c|}{ Dependent variable: 2-year employment change } \\
\hline & & $\begin{array}{l}\text { Almon correction } \\
\text { (third order) }\end{array}$ & $\begin{array}{l}\text { Restricted } \\
\text { coefficients }\end{array}$ \\
\hline Constant & & $\begin{array}{l}-0.89 \\
(1.30)\end{array}$ & \\
\hline Population density & & $\begin{array}{l}-0.03 \\
(0.03)\end{array}$ & \\
\hline Employment change $t-2$ & & $\begin{array}{l}0.42 \\
(0.05)^{* *}\end{array}$ & \\
\hline Individual start-up rate $t-0$ & $\mathrm{C} 0$ & $\begin{array}{l}-0.37 \\
(0.09)^{* *}\end{array}$ & 0.51 \\
\hline Individual start-up rate $t-1$ & $\mathrm{C} 1$ & $\begin{array}{l}-0.01 \\
(0.09)\end{array}$ & 0.13 \\
\hline Individual start-up rate $t-2$ & $\mathrm{C} 2$ & $\begin{array}{l}0.05 \\
(0.01)^{* *}\end{array}$ & -0.14 \\
\hline Individual start-up rate $t-3$ & $\mathrm{C} 3$ & $\begin{array}{l}0.00 \\
(0.01)\end{array}$ & -0.30 \\
\hline Individual start-up rate $t-4$ & & & -0.36 \\
\hline Individual start-up rate $t-5$ & & & -0.32 \\
\hline Individual start-up rate $t-6$ & & & -0.18 \\
\hline Individual start-up rate $t-7$ & & & 0.07 \\
\hline Individual start-up rate $t-8$ & & & 0.42 \\
\hline Organizational start-up rate $t-0$ & D0 & $\begin{array}{l}-0.43 \\
(0.15)^{* *}\end{array}$ & 0.99 \\
\hline Organizational start-up rate $t-1$ & D1 & $\begin{array}{l}-0.01 \\
(0.15)\end{array}$ & 0.33 \\
\hline Organizational start-up rate $t-2$ & D2 & $\begin{array}{l}0.07 \\
(0.02)^{* *}\end{array}$ & -0.11 \\
\hline Organizational start-up rate $t-3$ & D3 & $\begin{array}{l}-0.01 \\
(0.01)\end{array}$ & -0.35 \\
\hline Organizational start-up rate $t-4$ & & & -0.43 \\
\hline Organizational start-up rate $t-5$ & & & -0.38 \\
\hline Organizational start-up rate $t-6$ & & & -0.23 \\
\hline Organizational start-up rate $t-7$ & & & -0.02 \\
\hline Organizational start-up rate $t-8$ & & & 0.23 \\
\hline$R$-square & & 0.44 & \\
\hline Log-likelihood & & -467.28 & \\
\hline$N$ & & 200 & \\
\hline
\end{tabular}

OLS estimations with White standard errors and covariance (SE in parentheses)

Significance levels: ** $1 \%$; * $5 \%$

Note: This model is statistically inferior to the fourth-order model presented in the paper . 


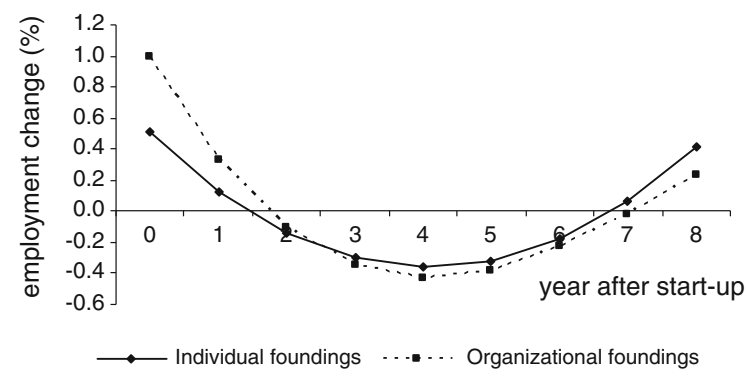

Fig. 4 Restricted coefficients based on third-order polynomial

\section{Appendix II}

See Figs. 5 and 6.

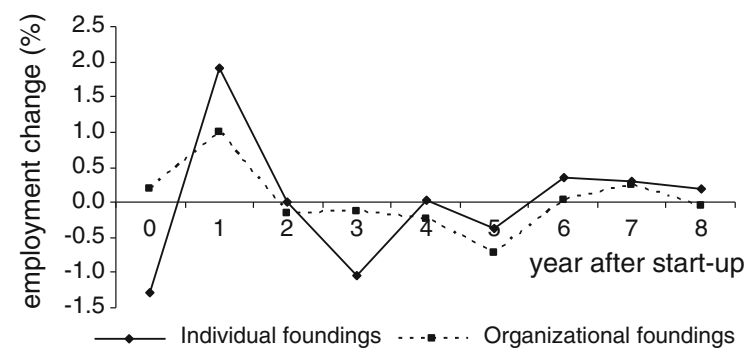

Fig. 5 Unrestricted coefficients of individual models

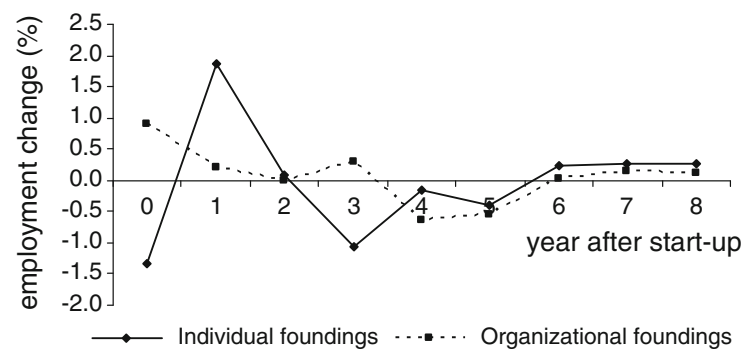

Fig. 6 Unrestricted coefficients of simultaneous model

\section{Appendix III}

See Table 5.
Table 5 GMM estimation of the simultaneous model

\begin{tabular}{|c|c|c|c|}
\hline & \multicolumn{3}{|c|}{$\begin{array}{l}\text { Dependent variable: } 2 \text {-year } \\
\text { employment change }\end{array}$} \\
\hline & & $\begin{array}{l}\text { Almon } \\
\text { correction } \\
\text { (fourth } \\
\text { order) }\end{array}$ & $\begin{array}{l}\text { Restricted } \\
\text { coefficients }\end{array}$ \\
\hline Population density & & $\begin{array}{l}0.03 \\
(0.03)\end{array}$ & \\
\hline Employment change $t-2$ & & $\begin{array}{l}-0.03 \\
(0.06)\end{array}$ & \\
\hline Individual start-up rate $t-0$ & $\mathrm{C} 0$ & $\begin{array}{l}-0.88 \\
(0.52)^{\dagger}\end{array}$ & -1.67 \\
\hline Individual start-up rate $t-1$ & $\mathrm{C} 1$ & $\begin{array}{l}-0.65 \\
(0.36)^{\dagger}\end{array}$ & 2.73 \\
\hline Individual start-up rate $t-2$ & $\mathrm{C} 2$ & $\begin{array}{l}0.78 \\
(0.14)^{* *}\end{array}$ & 2.35 \\
\hline Individual start-up rate $t-3$ & C3 & $\begin{array}{l}0.05 \\
(0.02)^{*}\end{array}$ & 0.45 \\
\hline Individual start-up rate $t-4$ & $\mathrm{C} 4$ & $\begin{array}{l}-0.05 \\
(0.01)^{* *}\end{array}$ & -0.88 \\
\hline Individual start-up rate $t-5$ & & & -0.75 \\
\hline Individual start-up rate $t-6$ & & & 0.55 \\
\hline Individual start-up rate $t-7$ & & & 1.56 \\
\hline Individual start-up rate $t-8$ & & & -0.37 \\
\hline $\begin{array}{l}\text { Organizational start-up rate } \\
t-0\end{array}$ & D0 & $\begin{array}{l}0.27 \\
(0.59)\end{array}$ & 2.20 \\
\hline $\begin{array}{l}\text { Organizational start-up rate } \\
t-1\end{array}$ & D1 & $\begin{array}{l}-0.05 \\
(0.34)\end{array}$ & 0.53 \\
\hline $\begin{array}{l}\text { Organizational start-up rate } \\
t-2\end{array}$ & D2 & $\begin{array}{l}-0.12 \\
(0.17)\end{array}$ & 0.20 \\
\hline $\begin{array}{l}\text { Organizational start-up rate } \\
t-3\end{array}$ & D3 & $\begin{array}{l}-0.02 \\
(0.02)\end{array}$ & 0.23 \\
\hline $\begin{array}{l}\text { Organizational start-up rate } \\
t-4\end{array}$ & D4 & $\begin{array}{l}0.01 \\
(0.01)\end{array}$ & 0.27 \\
\hline $\begin{array}{l}\text { Organizational start-up rate } \\
t-5\end{array}$ & & & 0.09 \\
\hline $\begin{array}{l}\text { Organizational start-up rate } \\
t-6\end{array}$ & & & -0.29 \\
\hline $\begin{array}{l}\text { Organizational start-up rate } \\
t-7\end{array}$ & & & -0.67 \\
\hline $\begin{array}{l}\text { Organizational start-up rate } \\
t-8\end{array}$ & & & -0.58 \\
\hline$J$ statistic & & 20.00 & \\
\hline$N$ & & 160 & \\
\hline
\end{tabular}

GMM estimation with cross-sectional effects based on orthogonal deviation and White period weights

$\mathrm{SE}$ in parentheses, significance levels: $* * 1 \% ; * 5 \% ;{ }^{\dagger} 10 \%$ 


\section{References}

Acs, Z. J., \& Armington, C. (2004). Employment growth and entrepreneurial activities in cities. Regional Studies, 38(8), 911-927.

Acs, Z. J., \& Mueller, P. (2008). Employment effects of business dynamics: Mice, gazelles and elephants. Small Business Economics, 30(1), 85-100.

Acs, Z. J., Audretsch, D., Braunerhjelm, P., Carlsson, B. (2006). The knowledge spillover theory of entrepreneurship. CESIS: Electronic Working Paper Series.

Arauzo Carod, J. M., Liviano Solis, D., \& Martín Bofarull, M. (2008). New business formation and employment growth: Some evidence for the Spanish manufacturing industry. Small Business Economics, 30(1), 73-84.

Audretsch, D., \& Fritsch, M. (2002). Growth regimes over time and space. Regional Studies, 36(2), 113-134.

Audretsch, D., \& Keilbach, M. (2004). Entrepreneurship and regional growth: An evolutionary interpretation. Journal of Evolutionary Economics, 14(5), 605-616.

Audretsch, D., \& Mahmood, T. (1994). The rate of hazard confronting new firms and plants in U.S. manufacturing. Review of Industrial Organization, 9(1), 41-56.

Baptista, R., \& Preto, M. T. (this issue). New firm formation and employment growth: Regional and business dynamics. Small Business Economics. doi:10.1007/s11187-0099254-y.

Baptista, R., Karaöz, M., \& Mendonça, J. (2007). Entrepreneurial backgrounds, human capital and start-up success. Jena: Friedrich Schiller University.

Baptista, R., Escária, V., \& Madruga, P. (2008). Entrepreneurship, regional development and job creation: The case of Portugal. Small Business Economics, 30(1), 49-58.

Barney, J. (1991). Firm resources and sustained competitive advantage. Journal of Management, 17(1), 99-120.

Baumol, W. J. (1990). Entrepreneurship: Productive, unproductive and destructive. The Journal of Political Economy, 98(5), 893-921.

Birch, D. L. (1979). The job generation process. Cambridge: MIT Press.

Bosma, N., \& Harding, R. (2007). Global entrepreneurship monitor. GEM 2006 results. London and Boston, MA: Babson College and London Business School.

Bosma, N., Stel, A. v., \& Suddle, K. (2008). The geography of new firm formation: Evidence from independent start-ups and new subsidiaries in the Netherlands. International Entrepreneurship and Management Journal, 4(2), 129146.

Braunerhjelm, P., \& Borgman, B. (2004). Geographical concentration, entrepreneurship and regional growth: Evidence from regional data in Sweden, 1975-99. Regional Studies, 38(8), 929-947.

Brüderl, J., Preisendörfer, P., \& Ziegler, R. (1992). Survival chances of newly founded business organizations. American Sociological Review, 57(2), 227-242.

Carree, M. (2002). Nearly unbiased estimation in dynamic panel data models. Rotterdam: Tinbergen Discussion Paper.

Chambers of Commerce (annually). Bedrijvendynamiek 19962006 (business dynamics). Woerden: Vereniging van Kamers van Koophandel.
Davidson, A. B., \& Ekelund, R. B. (1994). Can entrepreneurship be "unproductive"? Towards an evolutionary interpretation. Review of Social Economy, 52(4), 266-279.

Eckhardt, J. T., \& Shane, S. A. (2003). Opportunities and entrepreneurship. Journal of Management, 29(3), 333349.

Evans, D. S., \& Jovanovic, B. (1989). An estimated model of entrepreneurial choice under liquidity constraints. The Journal of Political Economy, 97(4), 808-827.

Fölster, S. (2000). Do entrepreneurs create jobs? Small Business Economics, 14(2), 137-148.

Frenken, K., Oort, F. v., Verburg, T., \& Boschma, R. A. (2004). Variety and regional economic growth in the Netherlands. Utrecht: Utrecht University.

Fritsch, M. (2008). How does new business formation affect regional development? Introduction to the special issue. Small Business Economics, 30(1), 1-14.

Fritsch, M., \& Mueller, P. (2004). Effects of new business formation on regional development over time. Regional Studies, 38(8), 961-975.

Fritsch, M., \& Mueller, P. (2007). The persistence of new business formation activity over time-assessing the potential of policy promotion programs. Journal of Evolutionary Economics, 17(3), 299-315.

Fritsch, M., \& Schroeter, A. (this issue). Why does the effect of new business formation differ across regions? Small Business Economics. doi:10.1007/s11187-009-9256-9.

Karlsson, C., \& Nyström, K. (2003). Exit and entry over the product life cycle: Evidence from the Swedish manufacturing industry. Small Business Economics, 21(2), 135144.

Klepper, S. J. (2001). Employee startups in high-tech industries. Industrial and Corporate Change, 10(3), 639-674.

Klepper, S. J., \& Simons, K. L. (2000). Dominance by birthright: Entry of prior radio producers and competitive ramifications in the US television receiver industry. Strategic Management Journal, 21(10/11), 997-1016.

Koster, S. (2006). Whose child? Hoe existing firms foster new firm formation: individual start-ups, spin-outs and spinoffs. Ph.D. Dissertation, Urban and Regional Studies Institute, Groningen University.

Koster, S. (2007). Window on the Netherlands: The entrepreneurial and replication function of new firm formation. Tijdschrift voor Economische en Sociale Geografie, 98(5), 667-674.

Mueller, P., Stel, A. v., \& Storey, D. J. (2008). The effects of new firm formation on regional development over time: The case of Great Britain. Small Business Economics, 30(1), 59-71.

Nickell, S. (1981). Biases in dynamic models with fixedeffects. Econometrica, 49(6), 1417-1426.

Penrose, E. T. (1959). The theory of the growth of the firm. Oxford: Blackwell.

Schumpeter, J. A. (1912). Theorie der wirtschaftlichen Entwicklung: eine Untersuchung über Unternehmengewinn, Kapital, Kredit, Zins und Konjunkturzyklus. München und Leipzig: Duncker and Humblot.

Shane, S. A. (2005). A general theory of entrepreneurship. The individual-opportunity nexus. Cheltenham, Northampton: Edward Elgar. 
Shrestha, S. S., Goetz, S. J., \& Rupasingha, A. (2007). Proprietorship formations and U.S. job growth. The Review of Regional Studies, 37(2), 146-168.

Stam, E. (2003). Why butterflies don't leave. Locational evolution of evolving enterprises. Ph.D Dissertation, University of Utrecht.

Stel, A. v., \& Storey, D. J. (2004). The link between firm births and job creation: Is there a upas tree effect? Regional Studies, 38(8), 893-909.

Stel, A. v., \& Suddle, K. (2008). The impact of new firm formation on regional development in the Netherlands. Small Business Economics, 30(1), 31-47.

Tübke, A. (2004). Success factors of corporate spin-offs. Boston: Kluwer Academic.

Ucbasaran, D., Westhead, P., \& Wright, M. (2006). Business ownership experience, information search, opportunity identification and pursuit. Nottingham: Nottingham University Business School.

Westhead, P., Ucbasaran, D., \& Wright, M. (2003). Differences between private firms owned by novice, serial and portfolio entrepreneurs: Implications for policy makers and practitioners. Regional Studies, 37(2), 187-200.

Weterings, A. B. R., \& Koster, S. (2007). Inheriting knowledge and sustaining relationships: What stimulates the innovative performance of software firms in the Netherlands? Research Policy, 36(3), 320-335.

Wong, P. K., Ho, Y. P., \& Autio, E. (2005). Entrepreneurship, innovation and economic growth: Evidence from GEM data. Small Business Economics, 24(3), 335-350. 